\title{
DESENTRALISASI FISKAL DAN PERTUMBUHAN EKONOMI, SERTA KAITANNYA DENGAN OTONOMI DAERAH ${ }^{1}$
}

\section{FISCAL DECENTRALIZATION AND ECONOMIC GROWTH, AND THE RELATION WITH REGIONAL AUTONOMY}

\author{
Rustan A. \\ PKP2A III Lembaga Administrasi N egara \\ JL. H.M Ardans (Ring Road III) Samarinda-Kalimantan Timur \\ Email : rustanamarullah8@gmail.com
}

\begin{abstract}
This study attempts to examine the influence of fiscal decentralization and regional autonomy on regional economic growth in Indonesia by using panel data analysis and the Hodrick-Prescott (HP) filter. This study takes sample at provincial level (selected 19 provinces) in Indonesia in the period of 1994-2010. Furthermore, to represents the fiscal decentralization this thesis uses three indicators, namely expenditure share, revenue share, and local government's own revenue share. Further, regional autonomy is treated as dummy variable with base year of 2004. The result demonstrates that fiscal decentralization is positively associated with economic growth in Indonesia, especially from the revenue side and own revenue side. The findings further strengthens the decentralization theorem and previous studies that mentioned fiscal decentralization play a role in foster the economic growth. In addition, it is also found that the implementation of regional autonomy policy (aggregate decentralization effect) presents positive relationship to economic growth.
\end{abstract}

Keywords : Fiscal Decentralization; Regional Autonomy; Economic Growth

\begin{abstract}
Abstrak
Studi ini mencoba untuk menguji pengaruh desentralisasi fiskal dan otonomi daerah terhadap pertumbuhan ekonomi daerah di Indonesia dengan menggunakan metode analisis data panel dan analisis Hodrick-Prescott (HP) filter. Studi ini mengambil sampel pada level provinsi (19 provinsi terpilih) di Indonesia pada periode 1994-2010. Indikator yang digunakan untuk mewakili pengukuran desentralisasi fiskal ada tiga, yaitu indikator rasio pengeluaran, indikator rasio pendapatan, dan indikator rasio pendapatan asli pemerintah
\end{abstract}

1 Naskah diterima pada 12 Agustus 2013, revisi pertama pada 11 November 2013, disetujui terbit pada 13 November 2013 Artikel ini merupakan intisari tesis penulis di International University of Japan disertai beberapa informasi tambahan. Penghargaan yang setinggi-tingginya penulis haturkan kepada Prof. Ching-Yang, Lin selaku supervisor tesis penulis di International University of Japan. 
daerah. Sedangkan otonomi daerah diperlakukan sebagai dummy variable dengan acuan tahun 2004 sebagai tahun dasar. Hasil analisis menunjukkan bahwa desentralisasi fiskal secara positif turut mempengaruhi pertumbuhan ekonomi di Indonesia, terutama dari sisi pendapatan dan dari sisi peningkatan pendapatan asli daerah. Temuan ini semakin memperkuat decentralization theorem dan studistudi sebelumnya yang menyebutkan bahwa desentralisasi fiskal cukup berperan penting dalam mendorong pertumbuhan ekonomi. Selain itu, juga ditemukan bahwa implementasi kebijakan otonomi daerah (aggregate effect desentralisasi) menunjukkan adanya hubungan positif terhadap peningkatan pertumbuhan ekonomi daerah.

Kata Kunci : Desentralisasi Fiskal; Otonomi Daerah; Pertumbuhan Ekonomi

\section{A. PENDAHULUAN}

Apakah desentralisasi fiskal ${ }^{2}$ memberikan kontribusi terhadap pertumbuhan ekonomi? Dari perspektif teoritis, Oates $(1972,2011)$ dan Tiebout (1956) menjelaskan bahwa terdapat hubungan positif antara desentralisasi fiskal dan pertumbuhan ekonomi. Namun secara empiris, masih belum terdapat kesimpulan yang solid diantara studi-studi terkait apakah desentralisasi fiskal bermanfaat bagi pertumbuhan ekonomi. Dengan demikian, masih terdapat ruang terbuka untuk memvalidasi secara akurat efek dari desentralisasi fiskal tersebut. Indonesia, sebagai negara yang telah menerapkan desentralisasi fiskal dan saat ini mencoba untuk memberikan desentralisasi fiskal yang lebih besar kepada daerah, merupakan sampel yang cukup relevan digunakan untuk menganalisis lebih jauh keterkaitan antara desentralisasi fiskal dan kesejahteraan ekonomi. Berdasarkan alasan-alasan tersebut, penelitian ini berusaha untuk menginvestigasi hubungan tersebut di Indonesia dengan menggunakan pendekatan yang cukup komprehensif sehingga the true effect dari desentralisasi fiskal dapat dijelaskan dengan baik. Selain itu, juga dilakukan analisis tambahan untuk melihat pengaruh pemberlakuan kebijakan otonomi daerah terhadap pertumbuhan ekonomi daerah.

Di Indonesia, semenjak penerapan otonomi daerah ${ }^{3}$, masalah tentang desentralisasi fiskal cukup menarik untuk dibahas. Alasannya adalah telah terjadi perubahan dalam skema desentralisasi fiskal saat ini yang memberikan dana perimbangan begitu besar dari pemerintah pusat ke pemerintah daerah, ditambah beberapa perluasan sumber-sumber pendapatan baru bagi pemerintah daerah. Selain itu, dengan alasan bahwa desentralisasi memberikan otonomi yang cukup luas bagi pemerintah daerah untuk mengelola dan mengatur urusan mereka sendiri sesuai dengan kebutuhan dan prioritas daerah, sehingga dapat diasumsikan bahwa hubungan antara desentralisasi fiskal terhadap pertumbuhan ekonomi

2 Definisi umum desentralisasi fiskal adalah transfer kewenangan yang terkait dengan pengambilan keputusan (perencanaan, management, peningkatan sumberdaya dan alokasi) dari pemerintah pusat kepada pemerintah level terendah (Rondinelli, 1989)

3 Manifestasi dari desentralisasi adalah otonomi daerah. Pemerintah pusat telah mengeluarkan serangkaian peraturan perundangan terkait otonomi daerah untuk memfasilitasi penerapan desentralisasi di Indonesia sejak tahun 2001. 
menjadi lebih efektif.

Hasil dari studi ini secara umum menunjukkan bahwa desentralisasi fiskal berdampak pada pertumbuhan ekonomi di Indonesia secara positif dan signifikan. Hasil ini kemudian memperkuat teorema desentralisasi dan studi-studi sebelumnya yang menyebutkan bahwa desentralisasi fiskal berperan cukup penting dalam mendorong pertumbuhan ekonomi. Selain itu, implementasi kebijakan otonomi daerah (decentralization effect) memberikan hubungan yang positif terhadap pertumbuhan ekonomi. Dengan mengetahui hubungan antara desentralisasi fiskal dan pertumbuhan ekonomi, policy maker dapat merumuskan kebijakan yang lebih tepat untuk memacu pembangunan daerah dan meningkatkan kesejahteraan masyarakat khususnya di era otonomi daerah saat ini.

Tulisan ini disusun ke dalam lima bagian. Bagian kedua berisi metode penelitian, kemudian bagian ketiga berisi landasan teoritis dan empiris. Bagian keempat merupakan review penerapan desentralisasi fiskal di Indonesia. Sedangkan bagian kelima adalah hasil dan pembahasan, yang berisi temuan-temuan yang diperoleh setelah dilakukan analisis ekonometrik dan implikasi yang ditimbulkannya. Selanjutnya, bagian keenam merupakan penutup yang berisi kesimpulan hasil penelitian dan rekomendasi kebijakan.

\section{B. METODE PENELITIAN}

\section{Jenis dan Sampel Penelitian}

Studi ini menggunakan pendekatan kuantitatif dengan menggunakan 2 (dua) alat analisis yaitu analisis panel data dan HodrickPrescott (HP) filter. Adapun sampel yang digunakan adalah level provinsi di Indonesia pada periode 1994-2010. Provinsi-provinsi yang digunakan merupakan 19 provinsi terpilih yang tidak mengalami pemekaran (dalam hal ini pembentukan provinsi baru dari provinsi existing) yaitu Aceh; Bali; Bengkulu; Jakarta; Jambi; Jawa Tengah; Jawa Timur; Kalimantan Barat; Kalimantan Selatan; Kalimantan Tengah; Kalimantan Timur; Lampung; Nusa Tenggara Barat; Nusa Tenggara Timur; Sulawesi Tengah; Sulawesi Tenggara; Sumatera barat; Sumatera Utara; dan Yogyakarta.

Alasan pemilihan sampel terpilih ini adalah untuk menghindari adanya pergerakan pertumbuhan ekonomi yang sangat tinggi atau sangat rendah yang terjadi secara tiba-tiba/ drastis akibat adanya pemekaran wilayah. Dengan metode pemilihan sampel seperti ini, real effect desentralisasi fiskal terhadap pertumbuhan ekonomi dapat ditangkap dengan baik oleh model analisis yang digunakan.

\section{Formulasi Persamaan Panel Data}

Model ekonometrik yang digunakan dalam tulisan ini mengikuti model teoritis pertumbuhan endogen yang dikembangkan oleh Barro (1988) dan juga digunakan oleh Davoodi dan Zou (1998), Akai dan Sakata (2002), dan Philip dan Isah (2012) dalam studi mereka. Dengan demikian, formulasi dasar regresi panel pertumbuhan dapat dituliskan sebagai berikut:

$$
E G_{i t}=\alpha_{0}+\alpha_{1} F D_{i t}+\alpha_{2} X_{i t}+\varepsilon_{i t} \ldots . .(1)
$$


Dimana i merujuk pada provinsi $i$ dan $t$ menunjukkan tahun $t . \mathrm{EG}_{i t}$ adalah pertumbuhan ekonomi regional yang diukur dengan pertumbuhan riil output per kapita. FD adalah indikator desentralisasi fiskal, dan $\varepsilon_{i t}$ menunjukkan gangguan/ error term.

Umumnya, terdapat banyak faktor selain desentralisasi fiskal yang mempengaruhi pertumbuhan ekonomi. Oleh karena itu, untuk mengontrol pengaruh faktor-faktor lainnya dan untuk meningkatkan robustness hasil yang diperoleh, digunakan sekumpulan variabel-variabel kontrol (Jin dan Zou, 2005). Berdasarkan persamaan di atas, $\mathrm{X}_{i t}$ kemudian merepresentasikan kontrol variabel yang terdiri dari variable-variabel yang umumnya digunakan untuk menjelaskan keterkaitan pertumbuhan ekonomi (Barro, 2003; Davoodi dan Zou, 1998; Iimi, 2005), yaitu:

\begin{tabular}{|c|c|}
\hline Variabel Kontrol & Penjelasan \\
\hline $\begin{array}{l}\text { Pendidikan Tenaga } \\
\text { Kerja }\end{array}$ & $\begin{array}{l}\text { Menggambarkan kualitas sumberdaya manusia, diukur dengan tingkat } \\
\text { pertumbuhan angkatan kerja kategori pendidikan tinggi (tingkat pendidikan } \\
\text { terakhir dari universitas dan diploma) dibandingkan dengan jumlah penduduk } \\
\text { tiap provinsi }\end{array}$ \\
\hline Tingkat Investasi & $\begin{array}{l}\text { : Menggambarkan tingkat investasi daerah, diukur dengan ratio Pembentukan } \\
\text { Modal Tetap Bruto (PMTB) terhadap PDRB }\end{array}$ \\
\hline Penerimaan Pajak & : $\quad$ Diukur dengan penerimaan pajak daerah dibagi dengan PDRB \\
\hline $\begin{array}{l}\text { Pertumbuhan } \\
\text { Penduduk }\end{array}$ & : Diukur dengan tingkat pertumbuhan penduduk tiap provinsi \\
\hline $\operatorname{GDPCAP}_{(-1)}$ & : Diukur dengan PRDB per kapita tahun sebelumnya untuk tiap provinsi \\
\hline
\end{tabular}

Kualitas sumberdaya manusia diharapkan berkorelasi positif dengan pertumbuhan ekonomi, sebab tenaga kerja dengan skill yang semakin tinggi (ditandai dengan tingkat pendidikan yang tinggi) akan semakin produktif dan mampu melakukan lebih banyak pekerjaan-pekerjaan kompleks (Blanchard, 2009). Tingkat investasi diyakini secara positif akan mendorong pertumbuhan ekonomi (Barro, 2003). Jumlah penduduk akan mempengaruhi baik positif atau negatif terhadap kinerja ekonomi (Amstrong dan Taylor, 2001). Tingkat Pajak sangat dipengaruhi oleh tingkat perkembangan ekonomi regional. Fenomena empiris menunjukkan bahwa semakin berkembang ekonomi daerah, semakin besar potensi pajak yang bisa digali dari masyarakat
(Kementerian Keuangan, 2012). Level awal PDRB per kapita menunjukkan apakah pertumbuhan ekonomi konvergen atau divergen ke level steady state jangka panjang. Ketika tingkat awal PRDB riil per kapita rendah, pertumbuhan ekonomi akan tumbuh secara positif atau konvergen (Barro, 2003).

Untuk mengukur desentralisasi fiskal (FD), metode yang umum diterapkan adalah dengan menggunakan ukuran-ukuran akuntansi yaitu ukuran pendapatan dan ukuran pengeluaran yang menunjukkan ukuran alokasi kewenangan (Akai dan Sakata, 2002) dan keuntungan efisiensi dari pemerintahan yang terdesentralisasi (Rodriguez-Pose dan Kroijer, 2009). Dikarenakan belanja publik dilakukan 
oleh tiga tingkatan pemerintah yaitu pemerintah pusat, pemerintah provinsi, dan pemerintah kabupaten/ kota. Maka, untuk mengukur desentralisasi fiskal, data yang digunakan dalam studi ini adalah data di tingkat pusat, tingkat provinsi, dan tingkat kabupaten/ kota. Desentralisasi fiskal (FD) kemudian diukur dengan menggunakan tiga proxy/pendekatan yaitu pendekatan pendapatan, pendekatan pengeluaran, dan pendekatan pendapatan asli daerah.

- Pendekatan Penerimaan. Indikator desentralisasi fiskal dari pendekatan ini diukur dengan rasio penerimaan provinsi (Akai dan Sakata, 2002). Indikator Penerimaan (RI) adalah rasio penerimaan pemerintah daerah terhadap penerimaan pemerintah pusat dan daerah. Penerimaan pemerintah daerah yang digunakan dalam studi ini terdiri dari penerimaan provinsi dan penerimaan Kabupaten/ Kota dalam provinsi tersebut yang dapat dirumuskan sebagai berikut:

$$
\begin{aligned}
& R I_{i t}=\frac{\text { Province Revenue }_{i t}}{\text { Central }_{t}+\text { Province Revenue }_{i t}} \\
& E G_{i t}=\alpha_{0}+\alpha_{1} R I_{i t}+\alpha_{2} X_{i t}+\varepsilon_{i t} \quad \ldots . . . .(2)
\end{aligned}
$$

- Pendekatan Pengeluaran. Indikator desentralisasi fiskal dari pendekatan ini diukur dengan rasio belanja provinsi (Akai dan Sakata, 2002; Iimi, 2005) Indikator Pengeluaran (EI) adalah rasio belanja pemerintah daerah (provinsi dan kabupaten / kota) terhadap pengeluaran pemerintah pusat dan daerah. Belanja atau pengeluaran pemerintah daerah yang digunakan dalam studi ini terdiri dari pengeluaran provinsi dan pengeluaran Kabupaten/ Kota dalam provinsi tersebut yang dapat dirumuskan sebagai berikut:

$$
\begin{aligned}
& E I_{i t}=\frac{\text { Province Expenditure }_{i t}}{\text { Central }_{t}+\text { Province Expenditure }_{i t}} \\
& E G_{i t}=\alpha_{0}+\alpha_{1} E I_{i t}+\alpha_{2} X_{i t}+\varepsilon_{i t}
\end{aligned}
$$

- Pendekatan Pendapatan Asli Daerah. Indikator ini menunjukkan tingkat kemandirian fiskal pemerintah daerah (Akai dan Sakata, 2002). Size dari otonomi daerah akan besar jika semua kebutuhan keuangan di wilayah tersebut mampu dibiayai sendiri oleh pemerintah daerah setempat, meskipun rasio penerimaan dan pengeluaran kecil. Dengan demikian, pertimbangan tingkat kemandirian daerah menjadi sangat penting dalam mengukur desentralisasi fiskal (Akai dan Sakata, 2002). Indikator pendapatan asli daerah (OR) diukur dengan rasio pendapatan asli pemerintah daerah (PAD) terhadap total penerimaan pemerintah daerah tersebut yang dapat dirumuskan sebagai berikut:

$$
\begin{gathered}
R I_{i t}=\frac{\text { Province Own Revenue }_{i t}}{\text { Total Province Revenue }_{i t}} \\
E G_{i t}=\alpha_{0}+\alpha_{1} \text { OR }_{i t}+\alpha_{2} X_{i t}+\varepsilon_{i t} \ldots .
\end{gathered}
$$

Selanjutnya, untuk menganalisis dampak otonomi daerah terhadap pertumbuhan ekonomi daerah, variabel dummy tahun (dummy otonomi daerah) digunakan dalam studi ini. Variabel dummy otonomi daerah ini mewakili kebijakan otonomi daerah. adapun tahun dasar pelaksanaan otonomi daerah yang digunakan dalam 
penelitian ini adalah tahun 2004 hingga 2010. Argumentasinya adalah pada tahun 2004 untuk pertama kalinya diadakan pemilihan langsung untuk memilih kepala daerah (Gubernur/ Bupati/ Walikota), sehingga diasumsikan periode ini menandai era sesungguhnya (direct and true impact) dari pelaksanaan otonomi daerah di daerah.

Selain itu, juga diperkenalkan variabel interaksi antara dummy otonomi daerah dan desentralisasi fiskal, yang dapat dirumuskan sebagai berikut:

$E G_{i t}=\alpha_{0}+\alpha_{1} F D_{i t}+\alpha_{2} X_{i t}+\alpha_{3} D_{u m D E C E N T} T_{i t}+\alpha_{3} D_{u m D E C E N T} T_{i t} * F D_{i t}+\varepsilon_{i t}$

Akhirnya diperoleh persamaan lengkap di atas untuk dianalisis lebih lanjut dalam studi ini dengan menerapkan metode analisis data panel dan Hodrick-Prescott filter.

\section{Formulasi Persamaan Hodrick- Prescott (HP) Filter}

Selain menggunakan analisis data panel sebagai model dasar (base model), studi ini juga melakukan analisis lebih lanjut dengan menghilangkan pengaruh siklus bisnis (business cycle) terhadap pertumbuhan ekonomi dari variabel-variabel yang digunakan. Hal ini dilakukan dengan cara memisahkan atau mengisolasi siklus perilaku ekonomi (economic series) dari pola atau trend jangka panjang yang biasanya terjadi dalam studi tentang pertumbuhan ekonomi. Pola atau trend pertumbuhan ekonomi biasanya dipengaruhi oleh faktorfaktor jangka panjang seperti imigrasi, kemajuan teknologi, tingkat pencapaian pendidikan, kelahiran, dan termasuk perubahan kelembagaan (Enders, 2010).

Hodrick-Prescott (HP) filter adalah teknik umum yang digunakan untuk mengisolasi komponenkomponen siklus dan untuk meminimalkan penyimpangan komponen siklus dari tingkat trend yang ada. Formulasi dasar HP-filter yang dikembangkan oleh Hodrick dan Prescott (1980, 1997) adalah serangkaian waktu dari $\mathrm{y}_{t}$ merupakan penjumlahan dari komponen pertumbuhan $\left(\mathrm{g}_{t}\right)$ dan komponen siklus $\left(c_{t}\right)$ :

$$
y_{t}=g_{t}+c_{t} \text { where } t=1, \ldots ., \mathrm{T} \text {. }
$$

Mulusnya (smoothness) hasil dari pola $\left\{\mathrm{g}_{t}\right\}$ dihitung dari jumlah kuadrat perbedaan kedua. Sedangkan $c_{t}$ merupakan deviasi dari $g_{t}$ dan kerangka konseptual HP-filter menyebutkan bahwa selama jangka waktu yang cukup lama, rata-rata deviasi tersebut mendekati nol. Poin-poin inilah yang menjadi dasar disusunnya formulasi pemrograman berikut untuk menentukan komponen pertumbuhan:

$\underset{\left\{g_{t}\right\}_{t=-1}^{T}}{\operatorname{Min}}\left\{\sum_{t=1}^{T} c_{t}^{2}+\lambda \sum_{t=1}^{T}\left[\left(g_{t}-g_{t-1}\right)-\left(g_{t-1}-g_{t-2}\right)\right]^{2}\right\}$

Dimana $\mathrm{c}_{t}=\mathrm{y}_{t}-\mathrm{g}_{t}$. Parameter $\lambda$ adalah angka positif dan mengakomodir variabilitas dalam series komponen pertumbuhan. Karena data yang digunakan adalah data tahunan, maka nilai dari smoothing parameter $\lambda$ yang digunakan adalah 6.25 (Ravn and Uhlig, 2002). 
Untuk memanfaatkan teknik ini, variabel dianalisis dalam bentuk natural logaritma sehingga perubahan dalam komponen pertumbuhan menjadi konsisten dengan tingkat pertumbuhan. Selain itu, untuk mengakomodir model data panel, semua variabel diproses secara terpisah untuk setiap provinsi dengan menggunakan teknik HP-filter, dan kemudian hasilnya akan dianalisis dengan menggunakan metode fixed effect.

\section{Sumber Data}

Data yang digunakan dalam studi ini adalah data sekunder yang dikumpulkan dari beberapa publikasi Badan Pusat Statistik Indonesia (BPS), Kementerian Keuangan Republik Indonesia, dan Kementerian Tenaga Kerja dan Transmigrasi Republik Indonesia. Secara khusus, data yang dikumpulkan untuk diolah dan dianalisis lebih lanjut yaitu, Produk Domestik Bruto Nasional (PDB) dan Produk Domestik Regional Bruto (PDRB) dari 19 provinsi periode 19942010, pendapatan daerah dan belanja daerah dari 19 provinsi periode 19942010, penerimaan pajak daerah dari 19 provinsi periode 1994-2010, tenaga kerja dengan tingkat pendidikan terakhir diploma dan universitas dari 19 provinsi periode 1994-2010, pembentukan modal tetap daerah (PMTB) dari 19 provinsi periode 19942010, dan jumlah penduduk dari 19 provinsi periode 1994-2010.

\section{KERANGKA TEORITIS DAN EMPIRIS}

Teori umum yang digunakan dalam menjelaskan hubungan antara desentralisasi fiskal dan pertumbuhan ekonomi adalah decentralization theorem yang dikembangkan oleh Oates (1972, 2011). Oates menyebutkan bahwa efisiensi ekonomi secara mendasar dapat ditingkatkan melalui delegasi dalam bentuk desentralisasi fiskal kepada pemerintah level terendah, se hing ga mengakibatkan terjadinya peningkatan pertumbuhan ekonomi baik pada tingkat nasional dan regional. Pemahaman yang sama juga diterangkan oleh Tiebout (1956) yang menyebutkan bahwa terdapat dua gagasan fundamental ekonomi dibalik desentralisasi fiskal yaitu, (1) melalui desentralisasi, efisiensi ekonomi dapat ditingkatkan karena pemerintah daerah mampu memberikan pelayanan publik yang lebih baik, dan (2) kompetisi dalam penyediaan pelayanan publik dan mobilitas penduduk antar pemerintah daerah akan terjadi dalam rangka untuk menyesuaikan dan mencocokkan antara preferensi masyarakat dengan pemerintah daerah.

Dari temuan-temuan empiris, kejelasan hubungan antara desentralisasi fiskal dan pertumbuhan ekonomi masih kurang meyakinkan. Beberapa studi menemukan korelasi hubungan yang positif seperti; studi dari Akai dan Sakata (2002) yang menggunakan data cross section dari 50 negara bagian Amerika Serikat periode 1992-1996, studi dari Jin dan Zou (2005) yang menggunakan data panel untuk 30 provinsi di Cina dengan analisis terpisah antara periode 19791993 dan 1994-1999, studi dari Feltenstein dan Iwata (2005) yang menggunakan data time series 19521996 di Cina, dan studi dari Iimi (2005) yang menginvestigasi data lintas negara periode 1997-2001. 
Di sisi lain, terdapat studi-studi sebelumnya yang menunjukkan bahwa terdapat hubungan yang negatif antara desentralisasi fiskal dan pertumbuhan ekonomi. Seperti studi dari Davoodi dan Zou (1998), yang menggunakan data panel untuk 46 negara selama kurun waktu 1970-1989. Mereka menemukan bahwa hubungan antara desentralisasi fiskal (yang diukur dengan proporsi pengeluaran pemerintah) dan pertumbuhan ekonomi menunjukkan korelasi yang negatif terutama di negara-negara berkembang. Studi lainnya yaitu Zhang dan Zhou (1998) dengan mengambil sample di Cina selama periode 19781992 menemukan bahwa ekonomi provinsi cenderung mengalami pertumbuhan negatif karena tingkat atau derajat desentralisasi fiskalnya (belanja pemerintah) yang lebih tinggi; dan temuan dari Rodriguez-Pose dan Kroijer (2009) menyimpulkan bahwa pengeluaran dan transfer kepada pemerintah level terendah memiliki hubungan negatif dengan tingkat pertumbuhan nasional di 16 negaranegara Eropa Tengah dan Eropa Timur (CEE) pada periode 1990-2004.

Di Indonesia sendiri, studi terkait hubungan desentralisasi fiskal terhadap pertumbuhan ekonomi juga belum menghasilkan kesimpulan yang solid. Studi dari Wibowo (2008) yang menggunakan data panel 29 provinsi periode 1999-2004 menemukan bahwa pada tingkat tertentu, kontribusi terhadap pembangunan ekonomi dapat dicapai, melalui pemberian delegasi fiskal lebih lanjut kepada pemerintah daerah. Sementara Swasono (2007) yang menggunakan sampel 367
Kabupaten/ Kota periode 1991-2005 menemukan bahwa desentralisasi fiskal cenderung memiliki dampak negatif pada pertumbuhan ekonomi.

Format desentralisasi fiskal di Indonesia telah berubah cukup signifikan, terutama setelah pemberlakuan otonomi daerah. Perubahan ini terlihat dari struktur transfer fiskal dalam bentuk dana perimbangan, proporsi transfer fiskal dari pemerintah pusat ke pemerintah daerah, dan perluasan basis pajak daerah dan retribusi. Dari perubahan ini, diharapkan agar daerah bisa meningkatkan pembangunan daerah, pertumbuhan ekonomi, dan kesejahteraan sosial yang lebih baik (UU No.32/2004)

Struktur transfer fiskal ke daerah sebelum otonomi daerah terdiri dari subsidi untuk daerah otonom (SDO) dan dana instruksi presiden (Inpres) atau dana pembangunan daerah. Di era ini, pelaksanaan desentralisasi fiskal dirasakan kurang efektif karena dominasi pemerintah pusat dalam mengatur alokasi dana ke daerah. Pemerintah pusat telah menetapkan jenis dana untuk setiap sektor-sektor pembangunan yang dianggap bermanfaat bagi pembangunan daerah, akibatnya pemerintah daerah kurang leluasa dalam membiayai pembangunan di daerah (Mahi, 2002)

Adapun struktur baru desentralisasi fiskal adalah dalam bentuk perimbangan keuangan antara pemerintah pusat dan pemerintah daerah (UU No. 22/ 1999 ${ }^{4}$ ) yang menggantikan SDO dan instrumen INPRES. Perimbangan keuangan ini dibagi menjadi tiga, yaitu dana alokasi 
umum (DAU), dana alokasi khusus (DAK), dan dana bagi hasil (DBH). Dalam format baru ini, bersama dengan kebijakan otonomi daerah, peran pemerintah pusat secara sederhana hanya mendistribusikan perimbangan keuangan ke daerah, dan pemerintah daerah memiliki kebebasan untuk membiayai pembangunan di daerahnya sesuai dengan prioritas dan kepentingan lokal. Namun demikian, sesuai dengan UU No 32/ 2004, pemerintah daerah diberi tugas untuk meningkatkan daya saing daerah, menyediakan infrastruktur dan pelayanan publik yang lebih baik (expenditure assignment), serta untuk mengumpulkan pajak, retribusi dan sumber pendapatan lainnya (revenue assignment) untuk membiayai kebutuhan-kebutuhan desentralisasi.

Dari penjelasan tersebut di atas, penelitian ini mencoba menguji pengaruh desentralisasi fiskal terhadap pertumbuhan ekonomi daerah di Indonesia dengan menggunakan pendekatan yang cukup sistematis. Selain menggunakan analisis data panel sebagai model dasar (base model), penelitian ini juga menggunakan analisis HodrickPrescott filter untuk memeriksa robustness atau konsistensi hasil yang diperoleh. Proxy yang digunakan untuk mewakili desentralisasi fiskal pada paper ini menggunakan tiga indikator ${ }^{5}$, yaitu share pengeluaran, share pendapatan, dan share pendapatan asli pemerintah daerah. Selain itu, penelitian ini menggunakan 19 provinsi terpilih yang tidak mengalami pemekaran wilayah dan turut memperhitungkan pengaruh otonomi daerah dalam model analisis yang digunakan.

\section{$R E$ V I E W P E N E R A P A N DESENTRALISASI FISKAL DI INDONESIA}

Jumlah transfer dana yang telah diberikan oleh pemerintah pusat kepada pemerintah daerah pada tahun 2007 sekitar 253 triliun rupiah dan akan meningkat sekitar 518 triliuin rupiah pada tahun 2013. Bila dihitung secara total dengan memperhitungkan semua pengeluaran dalam bentuk bantuan bagi masyarakat, subsidi, hibah, dan belanja pemerintah pusat di daerah, maka sekitar $60 \%$ dari belanja nasional telah dialihkan ke daerah (Martowardojo, 2012). Dengan jumlah dana transfer sebesar itu, daerah seharusnya mampu meningkatkan proporsi alokasi anggaran pembangunan untuk penyediaan infrastruktur dasar seperti pendidikan, kesehatan, jalan, pelabuhan, bandara, air bersih, irigasi, serta upaya lain yang dapat membawa manfaat ekonomi bagi daerah. Sama pentingnya, karena pemerintah daerah memiliki pemahaman yang lebih baik mengenai kondisi dan potensi daerah mereka daripada pemerintah pusat, dengan demikian efisiensi ekonomi dapat dicapai (Tiebout, 1956).

5 Hanya menggunakan satu indikator untuk merepresentasikan desentralisasi fiskal diragukan mampu memberikan hasil yang optimal dalam menangkap berbagai macam aspek dari desentralisasi fiskal (Akai dan Sakata, 2002) 
Tabel 1. Perbedaan Proporsi Keuangan Daerah Sebelum dan Setelah Otonomi Daerah

\begin{tabular}{lccc}
\hline \multicolumn{1}{c}{ Deskripsi } & $\begin{array}{c}\text { Sebelum Otonomi } \\
\text { Daerah }\end{array}$ & $\begin{array}{c}\text { Setelah Otonomi } \\
\text { Daerah }\end{array}$ & $\begin{array}{c}\text { ? \% } \\
\text { Perubahan }\end{array}$ \\
\cline { 2 - 3 } & $\mathbf{( 1 9 9 0 - 1 9 9 9 )}$ & $\mathbf{( 2 0 0 1 - 2 0 1 0 )}$ & \\
\hline $\begin{array}{l}\text { Rata-Rata Proporsi (\%) Transfer Keuangan } \\
\text { kepada Pemerintah Daerah }\end{array}$ & 24.11 & 33.07 & 37.16 \\
$\begin{array}{l}\text { Rata-Rata Total Penerimaan Pemerintah } \\
\text { Daerah (Juta Rp) }\end{array}$ & $9,676,520.72$ & $57,330,193.41$ & 492.47 \\
$\begin{array}{l}\text { Rata-Rata Penerimaan PAD Pemerintah } \\
\text { Daerah (Juta Rp) }\end{array}$ & $3,880,172.86$ & $25,080,080.30$ & 546.37 \\
\hline
\end{tabular}

Sumber : Nota Keuangan RAPBN (diolah oleh penulis)

Dibandingkan dengan periode sebelum dan sesudah otonomi daerah, tampak bahwa proporsi transfer dana dari pemerintah pusat ke pemerintah daerah telah meningkat dari $24.11 \%$ menjadi $33.07 \%$ dari total APBN. Selain itu, rata-rata total pendapatan pemerintah daerah dan PAD meningkat secara dramatis dengan persentase perubahan masing-masing $492.47 \%$ dan $546.37 \%$. Dengan komposisi pendapatan seperti ini, pemerintah daerah tentu akan mampu membiayai pembangunan daerah dan mendorong pertumbuhan ekonomi daerah lebih cepat daripada di masa sebelum otonomi daerah. Karena desentralisasi fiskal dapat meningkatkan kemampuan daerah dalam menciptakan iklim investasi yang lebih baik, meningkatkan pertumbuhan ekonomi, dan mendukung reformasi daerah (Freinkman dan Plekhanov, 2008).

Namun demikian, ada beberapa masalah yang biasanya terkait dengan otonomi daerah misalnya, korupsi, kemampuan dan kualitas pengambilan keputusan pemerintah yang rendah, dan kesenjangan antarwilayah yang makin besar, yang mungkin mempengaruhi rendahnya pertumbuhan ekonomi (Prud'homme, 1995). Selain itu, proporsi alokasi pembangunan, khususnya untuk infrastruktur dasar, belum digunakan secara efisien karena lemahnya pengelolaan keuangan daerah terutama yang berkaitan dengan penyerapan anggaran dan kemampuan untuk mengalokasikan belanja pemerintah daerah (Martowardojo, 2012). Oleh karena itu, masih timbul pertanyaan tentang hubungan antara besarnya dana desentralisasi fiskal dan peningkatan pembangunan daerah.

Masalah desentralisasi fiskal juga terlihat dari berbagai peraturan daerah yang dikeluarkan oleh pemerintah daerah untuk meningkatkan PAD melalui pajak dan retribusi, terutama setelah pelaksanaan kebijakan otonomi daerah. Akibatnya, kondisi ini menyebabkan ekonomi biaya tinggi dan menghambat kegiatan usaha dan investasi di daerah. Data dari Komite Pemantau Pelaksanaan Otonomi Daerah (KPPOD) tahun 2010 menyebutkan bahwa dari 3.735 perda yang dibuat antara tahun 2001 dan 2009, sekitar $31 \%$ termasuk dalam kategori penghambat ekonomi atau menyebabkan ekonomi biaya tinggi. Fakta inilah yang kemudian menjadi perdebatan apakah desentralisasi memang memberikan manfaat bagi bangsa atau lebih khusus bagi 
perekonomian daerah. Prud'homme (1995) berpendapat bahwa desentralisasi bahkan dapat menyebabkan peningkatan biaya, me m perbesar kesenjangan pembangunan, dan ketidakstabilan ekonomi makro.

\section{HASIL DAN PEMBAHASAN}

Sebelum menganalisis pengaruh desentralisasi fiskal terhadap pertumbuhan ekonomi, dilakukan analisis terhadap semua variabel kontrol dengan pertumbuhan ekonomi untuk mengkonfirmasi bahwa hasilnya konsisten dengan teori-teori pertumbuhan. Selain itu, diharapkan agar hasilnya tidak berubah atau konstan dalam analisis berikutnya, sehingga kita bisa fokus terutama pada efek desentralisasi fiskal terhadap pertumbuhan ekonomi.

Tabel 2. Hasil Regresi Data Panel dengan Seluruh Kontrol Variabel

\begin{tabular}{|c|c|c|c|}
\hline \multicolumn{4}{|c|}{ Dependen Variabel : Tingkat pertumbuhan riil PDRB per kapita } \\
\hline \multirow{2}{*}{ Kontrol Variabel } & $\begin{array}{l}\text { Pooled Least Square } \\
\text { (Common Effect) }\end{array}$ & Fixed Effect & Random Effect \\
\hline & $\begin{array}{c}\text { Koefisien } \\
\text { (standard error) }\end{array}$ & $\begin{array}{c}\text { Koefisien } \\
\text { (standard error) }\end{array}$ & $\begin{array}{c}\text { Koefisien } \\
\text { (standard error) }\end{array}$ \\
\hline \multirow[t]{2}{*}{ Tax Revenue } & $1.152 * * *$ & $2.892 * * *$ & $1.165^{* * *}$ \\
\hline & $(0.308)$ & $(0.637)$ & $(0.312)$ \\
\hline \multirow[t]{2}{*}{ Population Growth } & $-0.791 * * *$ & $-0.849 * * *$ & $-0.797 * * *$ \\
\hline & $(0.164)$ & $(0.169)$ & $(0.165)$ \\
\hline \multirow[t]{2}{*}{ Investment Rate } & $0.085^{* *}$ & -0.043 & $0.085^{* *}$ \\
\hline & $(0.040)$ & $(0.101)$ & $(0.042)$ \\
\hline \multirow[t]{2}{*}{ Workers Education } & $0.485^{* *}$ & $0.552 * *$ & $0.485^{* *}$ \\
\hline & $(0.217)$ & $(0.242)$ & $(0.218)$ \\
\hline \multirow[t]{2}{*}{ Initial per capita GDP } & $-0.014 * * *$ & $-0.143^{* * *}$ & $-0.034 * * *$ \\
\hline & $(0.005)$ & $(0.034)$ & $(0.005)$ \\
\hline \multirow[t]{2}{*}{ Constant } & $0.033 * * *$ & $0.272 * * *$ & $0.034 * * *$ \\
\hline & $(0.012)$ & $(0.067)$ & $(0.013)$ \\
\hline Number of Observation & 304 & 304 & 304 \\
\hline R-sq & 0.167 & & \\
\hline Within & & 0.2021 & 0.1522 \\
\hline Between & & 0.1847 & 0.4155 \\
\hline Overall & & 0.0492 & 0.1674 \\
\hline Adjusted R-sq & 0.153 & 0.200 & 0.151 \\
\hline Prob $>$ F & 0.0000 & 0.0000 & 0.0000 \\
\hline Durbin Watson Stat & 2.022 & 1.999 & 2.035 \\
\hline
\end{tabular}

* Signifikan pada $10 \%, * *$ signifikan pada $5 \%, * * *$ signifikan pada $1 \%$. 
Seperti terlihat pada tabel 2, hasilnya menunjukkan bahwa semua variabel kontrol secara statistik signifikan dan konsisten dengan teori pertumbuhan ekonomi atau penelitian sebelumnya, kecuali untuk tingkat investasi pada metode fixed effect. Penerimaan pajak, tingkat investasi, dan pendidikan tenaga kerja memberikan dampak yang positif dan signifikan terhadap pertumbuhan ekonomi. Pertumbuhan penduduk menunjukkan efek negatif dan secara statistik signifikan terhadap pertumbuhan ekonomi, sebagaimana Davoodi dan Zou (1998) jelaskan bahwa pertumbuhan ekonomi lebih tinggi di negara dengan tingkat pertumbuhan penduduk yang lebih rendah. Initial PDRB per kapita menunjukkan hasil negatif dan signifikan secara statistik yang berarti bahwa pertumbuhan ekonomi mengalami konvergensi (ceteris paribus) dan hal ini menunjukkan bahwa rendahnya tingkat PDRB per kapita sebelumnya mempengaruhi ekonomi saat ini untuk tumbuh lebih cepat.

Nilai statistik Durbin-Watson masih dalam interval $1.820-2.180$, yang berarti bahwa model yang digunakan terbebas dari masalah autokorelasi ( $\mathrm{k}=5$ dan $\alpha=5 \%$ ). Namun, kita masih perlu menentukan dan memilih metode analisis yang tepat untuk digunakan dalam analisis lebih lanjut. Untuk itu, dilakukan beberapa tes untuk setiap metode analisis yang digunakan.

Tabel 3. Hasil Test dari Seluruh Metode Panel Data

\begin{tabular}{lcccc}
\cline { 2 - 4 } & Chow test & Hausman test & $\begin{array}{c}\text { Breusch Pagan } \\
\text { Lagrange Multiplier } \\
(\text { LM }) \text { test }\end{array}$ & $\begin{array}{c}\text { Model } \\
\text { Terpilih }\end{array}$ \\
\hline $\begin{array}{l}\text { Pooled Least Square } \\
\text { atau Fixed Effect }\end{array}$ & Prob $=0.011$ & & Fixed Effect \\
$\begin{array}{l}\text { Fixed Effect atau } \\
\text { Random Effect }\end{array}$ & Prob>chi ${ }^{2}=0.002$ & & Fixed Effect \\
$\begin{array}{l}\text { Pooled Least Square } \\
\text { atau Random Effect }\end{array}$ & & Prob $>$ chibar $^{2}=0.354$ & $\begin{array}{c}\text { Pooled Least } \\
\text { Square }\end{array}$ \\
\hline
\end{tabular}

Dari keseluruhan test yang dilakukan sesuai tabel 3 di atas, dapat disiimpulkan bahwa metode yang paling tepat untuk digunakan dalam analisis lebih lanjut adalah metode fixed effect. Disamping itu, fixed effect adalah metode yang cukup baik untuk menghilangkan efek time invariant yang tidak teramati. Selanjutnya, ditambahkan dummy otonomi ke dalam model untuk mengamati peningkatan pertumbuhan ekonomi daerah setelah pelaksanaan otonomi daerah, dan terakhir ditambahkan variabel interaksi antara dummy otonomi dan desentralisasi fiskal.

\section{Hasil Pengolahan Data}

Untuk menghindari masalah multikolinearitas, proses perhitungan terhadap indikator fiskal dilakukan secara terpisah baik dalam analisis data panel (base model) maupun HP-filter. Berikut hasil lengkap perhitungan statistik dengan menggunakan metode fixed effect. 
Tabel 4. Hasil Regresi dengan Menggunakan Metode Fixed Effect

\begin{tabular}{|c|c|c|c|c|c|c|}
\hline \multicolumn{7}{|c|}{ Dependen Variabel : Tingkat pertumbuhan riil PDRB per kapita } \\
\hline Independen Variabel & \multicolumn{3}{|c|}{ Model 1 (Base Model) } & \multicolumn{3}{|c|}{ Model 2 (HP-Filter) } \\
\hline \multicolumn{7}{|l|}{ Indikator FD: } \\
\hline Ri & $\begin{array}{l}-0.033 \\
(0.267)\end{array}$ & & & $\begin{array}{c}0.039 * * * \\
(0.011)\end{array}$ & & \\
\hline Ei & & $\begin{array}{l}-0.010 \\
(0.077)\end{array}$ & & & $\begin{array}{c}0.010 \\
(0.008)\end{array}$ & \\
\hline OR & & & $\begin{array}{l}0.284^{* *} \\
(0.090)\end{array}$ & & & $\begin{array}{l}0.012^{*} \\
(0.008)\end{array}$ \\
\hline \multicolumn{7}{|l|}{ Dummy Otonomi: } \\
\hline DA & $\begin{array}{l}0.020^{*} \\
(0.012)\end{array}$ & $\begin{array}{l}0.019 * \\
(0.011)\end{array}$ & $\begin{array}{c}0.022 * * \\
(0.010)\end{array}$ & $\begin{array}{c}0.021 * * * \\
(0.002)\end{array}$ & $\begin{array}{c}0.017 * * * \\
(0.002)\end{array}$ & $\begin{array}{c}0.021 * * * \\
(0.003)\end{array}$ \\
\hline \multicolumn{7}{|l|}{ Variabel Interaksi : } \\
\hline $\mathrm{DA} * \mathrm{Ri}$ & $\begin{array}{l}-0.026 \\
(0.898)\end{array}$ & & & $\begin{array}{c}-0.049 * * * \\
(0.015)\end{array}$ & & \\
\hline $\mathrm{DA} * \mathrm{Ei}$ & & $\begin{array}{c}0.064 \\
(0.396)\end{array}$ & & & $\begin{array}{l}-0.022^{*} \\
(0.013)\end{array}$ & \\
\hline $\mathrm{DA} * \mathrm{OR}$ & & & $\begin{array}{c}0.345 \\
(0.045)\end{array}$ & & & $\begin{array}{c}-0.023^{* *} \\
(0.012)\end{array}$ \\
\hline \multicolumn{7}{|l|}{ Kontrol Variabel : } \\
\hline Tax Revenue & $\begin{array}{c}2.055^{* * * *} \\
(0.695)\end{array}$ & $\begin{array}{l}2.037 * * \\
(0.701)\end{array}$ & $\begin{array}{c}1.151 \\
(0.769)\end{array}$ & $\begin{array}{c}-0.033 * * * \\
(0.006)\end{array}$ & $\begin{array}{c}-0.030 * * * \\
(0.006)\end{array}$ & $\begin{array}{c}-0.026^{* * * *} \\
(0.007)\end{array}$ \\
\hline Workers Education & $\begin{array}{c}0.548^{* *} \\
(0.245)\end{array}$ & $\begin{array}{l}0.541^{* *} \\
(0.246)\end{array}$ & $\begin{array}{l}0.536 * * \\
(0.248)\end{array}$ & $\begin{array}{l}-0.002 \\
(0.012)\end{array}$ & $\begin{array}{c}-0.004 \\
(0.013)\end{array}$ & $\begin{array}{l}-0.009 \\
(0.013)\end{array}$ \\
\hline Investment Rate & $\begin{array}{c}0.043 \\
(0.101)\end{array}$ & $\begin{array}{c}0.044 \\
(0.093)\end{array}$ & $\begin{array}{c}0.002 \\
(0.092)\end{array}$ & $\begin{array}{c}0.001 \\
(0.013)\end{array}$ & $\begin{array}{c}0.013 \\
(0.013)\end{array}$ & $\begin{array}{c}0.002 \\
(0.013)\end{array}$ \\
\hline Population Growth & $\begin{array}{c}-0.877^{* * *} \\
(0.134)\end{array}$ & $\begin{array}{c}-0.859 * * * \\
(0.134)\end{array}$ & $\begin{array}{c}-0.853^{* * *} \\
(0.131)\end{array}$ & $\begin{array}{c}-5.440 * * * \\
(0.675)\end{array}$ & $\begin{array}{c}-5.085^{* * *} \\
(0.681)\end{array}$ & $\begin{array}{c}-5.876 * * * \\
(0.679)\end{array}$ \\
\hline Initial per capita GDP & $\begin{array}{c}-0.138^{* * *} \\
(0.031)\end{array}$ & $\begin{array}{c}-0.138^{* * *} \\
(0.031)\end{array}$ & $\begin{array}{c}-0.145^{* * * *} \\
(0.031)\end{array}$ & $\begin{array}{c}0.947^{* * *} \\
(0.051)\end{array}$ & $\begin{array}{c}0.978^{* * *} \\
(0.052)\end{array}$ & $\begin{array}{c}0.938^{* * *} \\
(0.051)\end{array}$ \\
\hline Konstanta & $\begin{array}{c}0.241^{* * *} * \\
(0.062)\end{array}$ & $\begin{array}{c}0.240 * * * \\
(0.061)\end{array}$ & $\begin{array}{c}0.234 * * * \\
(0.061)\end{array}$ & $\begin{array}{c}0.003 \\
(0.003)\end{array}$ & $\begin{array}{l}0.006 * * \\
(0.003)\end{array}$ & $\begin{array}{c}0.004 \\
(0.004)\end{array}$ \\
\hline $\begin{array}{l}\text { Number of } \\
\text { Observation }\end{array}$ & 304 & 304 & 303 & 285 & 285 & 285 \\
\hline R-sq Within & 0.215 & 0.215 & 0.242 & 0.877 & 0.881 & 0.881 \\
\hline Between & 0.205 & 0.206 & 0.290 & 0.733 & 0.721 & 0.747 \\
\hline Overall & 0.057 & 0.057 & 0.080 & 0.814 & 0.813 & 0.820 \\
\hline Prob $>F$ & 0.000 & 0.000 & 0.000 & 0.000 & 0.000 & 0.000 \\
\hline
\end{tabular}

* signifikan pada $10 \%$, ${ }^{*}$ signifikan pada $5 \%, * * *$ signifikan pada $1 \%$.

Standard error dalam tanda kurung

Berdasarkan tabel 4 tersebut, dengan fokus pada indikator desentralisasi fiskal, tampak bahwa hasil regresi dari base model menunjukkan hasil yang signifikan untuk desentralisasi fiskal hanya pada sisi pendapatan asli daerah. Sedangkan setelah melakukan analisis HP-filter menunjukkan hasil yang positif dan signifikan secara statistik (robust) pada sisi penerimaan dan sisi pendapatan asli daerah. Perbedaan hasil ini mungkin terjadi karena adanya pengaruh dari siklus bisnis (business 
cycle) dalam base model sehingga mengaburkan efek nyata dari desentralisasi fiskal.

Hasil regresi dari sisi penerimaan $\left(\mathrm{R}_{i}\right)$ menunjukkan bahwa desentralisasi fiskal berdampak positif dan signifikan terhadap pertumbuhan ekonomi. Efek parsial $\mathrm{R}_{i}$ terhadap pertumbuhan ekonomi adalah 0,039. Kemudian dengan memperhatikan perubahan struktural desentralisasi fiskal dalam hubungannya dengan pelaksanaan otonomi daerah, diperoleh total efek desentralisasi fiskal dari sisi penerimaan sebagai berikut (dengan asumsi variabel lain ceteris paribus):

Dari model HP-filter diperoleh, $\mathrm{Y}=0.039\left(\mathrm{R}_{i}\right)-0.049\left(\mathrm{DA}^{*} \mathrm{R}_{i}\right)$, dan efek dari rasio penerimaan terhadap pertumbuhan ekonomi setelah otonomi daerah adalah $\frac{\partial Y}{\partial R_{i}}=0.039-0.049=-0.01$

Adapun efek dari rasio penerimaan terhadap pertumbuhan ekonomi sebelum otonomi daerah adalah 0.039 . Dengan demikian, total effect $\mathrm{R}_{i}$ adalah $0.039+(-0.01)=0.029$. Hasil ini menunjukkan bahwa desentralisasi fiskal mempengaruhi pertumbuhan ekonomi secara positif dan signifikan meskipun pengaruhnya masih kecil.

Temuan ini menunjukkan bahwa peningkatan pendapatan pemerintah daerah bersamaan dengan perluasan basis pajak daerah dan retribusi daerah dapat memberikan stimulus positif bagi pertumbuhan ekonomi daerah. Masih kecilnya efek desentralisasi fiskal dalam hal penerimaan dapat terjadi karena pelaksanaan undang-undang yang mengatur perluasan basis pajak daerah dan retribusi daerah baru berjalan efektif pada tahun 2009. Akibatnya, optimalisasi pendapatan pemerintah daerah sebagai stimulus fiskal terhadap pertumbuhan ekonomi masih belum terlihat. Selain itu, pemerintah daerah juga belum optimal berupaya mengoptimalkan badan usaha milik daerah sebagai salah satu sumber pendapatan daerah potensial.

Di sisi lain, diakui bahwa pendapatan asli pemerintah daerah masih lebih kecil dibandingkan dengan dana perimbangan dari pemerintah pusat yang mencapai hampir $60 \%$ dari APBD. Data dari Unit Desentralisasi Fiskal, Tim Asistensi Kementerian Keuangan 2008 menunjukkan bahwa dari tahun 2001 sampai 2005, pendapatan daerah dari pajak dan retribusi hanya kurang dari $10 \%$, namun saat ini meningkat menjadi $10 \%$ $-20 \%$ seiring dengan ekspansi sumbersumber pajak pemerintah daerah. Transfer fiskal dari pemerintah pusat pada dasarnya adalah pemerataan fiskal yang sangat penting untuk mengurangi kesenjangan pendanaan antara pemerintah pusat dan daerah (ketidakseimbangan vertikal) dan untuk mengurangi kesenjangan pendanaan antar pemerintah daerah (ketidakseimbangan horisontal) dalam rangka memberikan pelayanan publik dengan standar yang sama secara nasional (Mochida, 2008). Dengan demikian, dapat dikatakan bahwa peran pemerintah pusat dalam mendorong pertumbuhan ekonomi daerah masih cukup penting.

Hasil regresi dari sisi pengeluaran $\left(\mathrm{E}_{i}\right)$ memperlihatkan bahwa efek parsial desentralisasi fiskal telah memberikan kontribusi positif meskipun tidak signifikan secara statistik terhadap pertumbuhan ekonomi regional. Pengaruh parsial dari base model menunjukkan bahwa jika rasio belanja pemerintah daerah 
meningkat sebesar 1 poin, maka pertumbuhan ekonomi akan meningkat sebesar $0,01 \%$. Selanjutnya, efek total pengeluaran terhadap pertumbuhan ekonomi sebagai berikut (ceteris paribus):

Dari model HP-filter diperoleh, $\mathrm{Y}=0.010\left(\mathrm{E}_{i}\right)-0.022\left(\mathrm{DA}^{*} \mathrm{E}_{i}\right)$, dan efek dari rasio pengeluaran terhadap pertumbuhan ekonomi setelah otonomi daerah adalah

$$
\frac{\partial Y}{\partial E_{i}}=0.010-0.022=-0.012
$$

Sedangkan efek dari rasio pengeluaran terhadap pertumbuhan ekonomi sebelum otonomi daerah adalah 0.010. Maka, efek total dari $\mathrm{E}_{i}$ adalah $0.010+(-0.012)=-0.002$. Karena hasil regresi menunjukkan bahwa $E_{i}$ secara statistik tidak signifikan, sehingga tidak cukup bukti untuk menyimpulkan bahwa efek total desentralisasi fiskal dari sisi pengeluaran mempengaruhi pertumbuhan ekonomi secara negatif.

Adanya indikasi positif dari efek parsial dapat berarti bahwa pemerintah daerah secara aktif berusaha untuk memenuhi semua kebutuhan pembangunan regional seperti, infrastruktur dasar, pendidikan, dan kesehatan. Pengeluaran pemerintah daerah sebelum pelaksanaan otonomi daerah di sektor pendidikan hanya $6 \%$ dan sektor kesehatan sebesar $4 \%$ dari total pengeluaran pemerintah. Namun, setelah pelaksanaan otonomi daerah, serta untuk mematuhi peraturan dibidang pendidikan dan kesehatan, pemerintah daerah saat ini menghabiskan setidaknya $20 \%$ dari total pengeluaran pemerintah di sektor pendidikan dan minimal $10 \%$ untuk sektor kesehatan.
Peningkatan jumlah belanja pemerintah daerah mencerminkan meningkatnya jumlah investasi barang publik yang secara tidak langsung mempengaruhi output sektor private. Namun, mungkin terdapat titik optimal dari desentralisasi fiskal, atau dengan kata lain jika rasio penerimaan fiskal pemerintah daerah dan pengeluaran sudah cukup tinggi, maka pemberian desentralisasi yang lebih besar justru dapat memperlambat pertumbuhan ekonomi (Zhang dan Zou, 1998; Xie, Zou dan Davoodi, 1999; MartinezVazquez dan McNab, 2003).

Hasil regresi dari sisi Pendapatan Asli Daerah (OR) menunjukkan bahwa desentralisasi fiskal berdampak positif dan signifikan terhadap pertumbuhan ekonomi. Dari base model dapat diketahui bahwa efek parsial OR terhadap pertumbuhan ekonomi adalah 0.284. Ini berarti bahwa jika share Pendapatan Asli Daerah naik meningkat sebesar 1 point, akan meningkatkan pertumbuhan ekonomi sebesar $0.28 \%$. Sedangkan dari model HP-filter, efek parsial OR terhadap pertumbuhan ekonomi adalah 0.012 . Ke mudian dengan memperhatikan perluasan basis pajak daerah dan retribusi daerah bersamaan dengan penerapan otonomi daerah, maka diperoleh total efek desentralisasi fiskal dari sisi pendapatan asli daerah sebagai berikut (dengan asumsi variabel lain ceteris paribus):

Dari base model diperoleh, $\mathrm{Y}=0.284\left(\mathrm{OR}_{i}\right)+0.345\left(\mathrm{DA}^{*} \mathrm{OR}_{i}\right)$, dan efek dari rasio pendapatan asli daerah terhadap pertumbuhan ekonomi setelah otonomi daerah adalah.

$$
\frac{\partial Y}{\partial O R_{i}}=0.284+0.345=0.629
$$


Sedangkan efek dari rasio pendapatan asli daerah terhadap pertumbuhan ekonomi sebelum otonomi daerah adalah 0.284. Maka, efek total OR adalah $0.284+0.629=$ 0.913. Hasil positif ini juga dikonfirmasi oleh model HP-filter sebagai berikut:

Diperoleh, $\mathrm{Y}=0.012\left(\mathrm{Or}_{i}\right)-0.023$ $\left(\mathrm{DA} * \mathrm{OR}_{i}\right.$ ) dari model HP-filter, dan efek dari rasio pendapatan asli daerah terhadap pertumbuhan ekonomi setelah otonomi daerah adalah

$$
\frac{\partial Y}{\partial O R_{i}}=0.012-0.023=-0.011
$$

Sedangkan efek dari rasio pendapatan asli daerah terhadap pertumbuhan ekonomi sebelum otonomi daerah adalah 0.012. Maka efek total OR adalah $0.012+(-0.011)=$ 0.001 . Hasil ini menunjukkan bahwa desentralisasi fiskal mempengaruhi pertumbuhan ekonomi secara positif dan signifikan. Ini mengindikasikan bahwa perluasan basis pajak daerah dan retribusi daerah, serta optimalisasi badan usaha milik daerah cukup efektif untuk mendorong peningkatan pertumbuhan ekonomi daerah.

Positif dan signifikan efek desentralisasi fiskal di Indonesia, yang diukur dengan rasio penerimaan dan rasio pendapatan asli pemerintah daerah semakin memperkuat teorema desentralisasi yang berpendapat bahwa desentralisasi fiskal dapat meningkatkan pertumbuhan ekonomi daerah (Oates, 1972). Hasil studi ini juga konsisten dengan studi-studi sebelumnya seperti, Akai dan Sakata (2002), Jin dan Zou (2005), Iimi (2005), dan Wibowo (2008).

Kebijakan otonomi daerah juga menggambarkan efek positif dan signifikan terhadap pertumbuhan ekonomi meskipun efeknya tidak begitu besar. Berdasarkan hasil yang diperoleh, pertumbuhan ekonomi meningkat rata-rata $0.02 \%$ per tahun di bawah otonomi daerah sejak tahun 2004. Sejak otonomi daerah diimplementasikan, kegiatan ekonomi dan bisnis berkembang cukup intensif (Departemen Keuangan, 2012). Investor dapat dengan mudah mengajukan permohonan perizinan di daerah dan pemerintah daerah secara kreatif melakukan berbagai upaya untuk menarik investor ke daerah termasuk kemudahan untuk melakukan bisnis di daerah. Kondisi lain yang mendukung yaitu peranan partai politik menjadi lebih kuat setelah otonomi daerah. Partai politik memiliki peranan penting untuk mempengaruhi efek desentralisasi terhadap pertumbuhan ekonomi, penyediaan barang publik, dan peningkatan kualitas pemerintah (Enikolopov dan Zhuravskaya, 2007).

Di era otonomi daerah keterlibatan dan partisipasi sektor swasta dalam pembangunan daerah dan penyediaan barang dan jasa publik cukup tinggi. Hal ini dibuktikan dengan adanya kesepakatan bersama antara pemerintah daerah dan sektor swasta dalam bentuk public private partnership (PPP) meliputi bidang pelayanan administrasi dan pelayanan barang dan jasa. Beberapa contoh PPP yang biasanya dilakukan oleh pemerintah daerah di Indonesia, yaitu, pembangunan dan pengelolaan pelabuhan, telekomunikasi, pengoperasian parkir dan limbah, pembangunan dan pengelolaan jalan, dan pembangunan dan managemen mall dan pasar. Pelayanan yang dilakukan oleh swasta sangat 
bermanfaat untuk menutupi keterbatasan pemerintah daerah, selain itu berguna untuk menghindari adanya monopoli penyediaan layanan publik, yang seringkali tidak efisien dan kualitas layanannya buruk (Litvak, Ahmad, dan Bird., 1998).

Namun, mengingat fakta bahwa terdapat faktor dari perubahan kelembagaan yang mempengaruhi efektivitas otonomi daerah dalam mendorong pertumbuhan ekonomi. Sebagaimana Martinez-Vazquez dan McNab (2003) jelaskan bahwa desentralisasi mungkin dapat mempengaruhi pertumbuhan ekonomi melalui cara yang lain, dalam hal ini efek totalnya tergantung pada kombinasi dari efek langsung dan efek tidak langsung. Oleh karena itu, sangat penting untuk menghitung efek agregat otonomi daerah terhadap pertumbuhan ekonomi dengan menggunakan perhitungan sebagai berikut (dengan asumsi variabel lain tidak berubah):

\section{Sisi Penerimaan}

Dari model HP-filter diperoleh, $\mathrm{Y}=0.021$ ( D A) $-0.049\left(\mathrm{DA}^{*} \mathrm{R}_{i}\right.$ ), sehingga efek total otonomi daerah terhadap pertumbuhan ekonomi adalah

$\frac{\partial Y}{\partial D A}=0.021-0.049\left(0.131^{6}\right)=0.015$.

2. Sisi Pengeluaran

Dari model HP-filter diperoleh, $\mathrm{Y}=0.017(\mathrm{DA})-0.022\left(\mathrm{DA}^{*} \mathrm{E}_{i}\right)$, dan efek total otonomi daerah terhadap pertumbuhan ekonomi adalah

$\frac{\partial Y}{\partial D A}=0.017-0.022\left(0.018^{7}\right)=0.017$.
3. Sisi Pendapatan Asli Daerah

Dari model HP-filter diperoleh, $\mathrm{Y}=0.021(D A)-0.023\left(D A * O R_{i}\right)$, sehingga efek total otonomi daerah terhadap pertumbuhan ekonomi adalah

$\frac{\partial Y}{\partial D A}=0.021-0.023\left(0.134^{8}\right)=0.018$.

Hasil perhitungan di atas menunjukkan bahwa otonomi daerah memberikan kontribusi positif terhadap pertumbuhan ekonomi. Hal ini menunjukkan bahwa dalam era otonomi daerah, dimana pemerintah daerah diberikan kebebasan untuk mengelola urusan mereka sendiri, alokasi anggaran untuk penyediaan layanan publik dan pembangunan daerah cukup efektif dan sukses merangsang ekonomi daerah. Dengan kata lain, otonomi membuat pemerintah daerah dapat mengoptimalkan pendapatan dan pengeluaran mereka untuk meningkatkan kualitas pembangunan daerah. Hasil ini juga sesuai dengan penelitian Wibowo (2008) yang menyebutkan bahwa desentralisasi fiskal di era otonomi daerah relatif lebih bermanfaat dalam mendukung kinerja ekonomi dibandingkan orde sebelumnya.

Meskipun demikian, untuk meningkatkan efektivitas otonomi daerah terhadap pertumbuhan ekonomi, seperti yang dijelaskan oleh Davoodi dan Zou (1998) yang menyebutkan belanja pemerintah daerah harus dapat dibedakan antara belanja modal, belanja infrastruktur, jaminan sosial, dan current spending

8 Nilai rata-rata $\mathrm{OR}_{2}$ 
(termasuk upah dan gaji). Pertumbuhan ekonomi akan positif melalui belanja modal dan infrastruktur, dan efek pertumbuhan ekonomi akan negatif melalui pengeluaran untuk kesejahteraan (jaminan sosial) dan current spending. Bahkan jika tugas pengeluaran sudah optimal, pengeluaran yang berlebihan oleh pemerintah daerah pada pos pengeluaran yang salah dapat menyebabkan pertumbuhan ekonomi yang lebih rendah. Oleh karena itu, peningkatan kemampuan pemerintah daerah dalam pengelolaan keuangan daerah pada dasarnya masih terus diperlukan. Konsepsi diatas dibuktikan dan dipertegas dengan data statistik yang ada antara tahun 2005-2011 yang menunjukkan bahwa proporsi belanja modal masih cukup kecil dibandingkan belanja pegawai.

Tabel 5. Perbandingan Jenis Realisasi Belanja Pemerintah Daerah Tahun 2005-2011

\begin{tabular}{lrrrrrr}
\hline \multirow{2}{*}{ Belanja } & \multicolumn{2}{c}{ Provinsi } & \multicolumn{2}{c}{ Kabupaten/ Kota } & \multicolumn{2}{c}{$\begin{array}{c}\text { Provinsi dan } \\
\text { Kabupaten/ Kota }\end{array}$} \\
\cline { 2 - 8 } & \multicolumn{1}{c}{ Jutaan Rp } & \multicolumn{1}{c}{$\%$} & \multicolumn{1}{c}{ Jutaan Rp } & \multicolumn{1}{c}{$\%$} & \multicolumn{1}{c}{ Jutaan Rp } & \multicolumn{1}{c}{$\%$} \\
\hline Pegawai & 22.133 .208 & 20,8 & 137.572 .060 & 41,95 & 159.705 .268 & 36,8 \\
Barang dan Jasa & 20.061 .358 & 18,85 & 49.723 .886 & 15,16 & 69.785 .244 & 16,1 \\
Modal & 20.789 .212 & 19,45 & 75.153 .505 & 22,92 & 95.942 .717 & 22,0 \\
Lainnya*) & 43.420 .931 & 40,81 & 65.474 .614 & 19,97 & 108.895 .545 & 25,1 \\
\hline Total & 106.404 .709 & 100 & 327.924 .065 & 100 & 434.328 .774 & 100 \\
\hline
\end{tabular}

*) Bantuan sosial, bantuan keuangan, hibah, pembiayaan daerah, tak terduga, dan lain-lain Sumber: BPS, 2013 dalam Saputra (2013)

Berdasarkan data diatas terlihat bahwa rata-rata belanja pemerintah daerah masih didominasi oleh belanja pegawai. Adapun belanja modal yang berperan penting dalam menggerakkan perekonomian daerah masih belum mendapatkan porsi yang cukup besar. Kondisi ini tentunya perlu ditata kembali agar pertumbuhan ekonomi khususnya per kapita dapat meningkat lebih cepat sehingga kesejahteraan masyarakat pun dapat ditingkatkan. Pemerintah pusat sebenarnya telah mendorong pemerintah daerah untuk melakukan penghematan pada porsi belanja pegawai dan mengalokasikan secara proporsional bagi belanja pembangunan (modal) ${ }^{9}$. Investasi swasta memang dapat diandalkan menjadi pemicu pertumbuhan ekonomi daerah namun jumlahnya masih belum siginifikan, sehingga peran belanja modal pemerintah sangat diperlukan.

\section{E. PENUTUP}

Penelitian ini memiliki tujuan umum untuk menganalisis dampak desentralisasi fiskal terhadap pertumbuhan ekonomi di Indonesia. Secara khusus, penelitian ini bertujuan untuk menganalisis apakah desentralisasi fiskal mempengaruhi pertumbuhan ekonomi, dan untuk menganalisis dampak dari pelaksanaan kebijakan otonomi daerah terhadap pertumbuhan ekonomi. Analisis

9 Daerah Boros Belanja Pegawai. Tanggal 1 Mei 2012, available on http://www.kppod.org/index.php/en/berita/berita-media/149daerah-boros-belanja-pegawai 
dilakukan terhadap 19 provinsi terpilih periode 1994-2010 dengan menggunakan metode fixed effect pada analisis data panel dan analisis Hodrick-Prescott (HP) filter.

Dari hasil studi ini, dapat disimpulkan bahwa desentralisasi fiskal memberikan kontribusi positif terhadap pertumbuhan ekonomi daerah, baik dari sisi pendapatan dan sisi pendapatan asli daerah. Namun, hasil ini juga mengindikasikan bahwa pengeluaran pemerintah daerah masih perlu ditata sehingga tidak didominasi oleh belanja pegawai dan belanja administrasi. Untuk meningkatkan pendapatan daerah, pemerintah daerah dapat mengoptimalkan pendapatan asli daerah dari basis pajak baru dan retribusi daerah, serta dari badan usaha milik daerah. Dengan demikian, struktur keuangan daerah untuk pembangunan daerah dan penyediaan pelayanan publik dapat diperbesar. Sehingga akan mendorong kegiatan ekonomi dan kesejahteraan masyarakat.

Dari studi ini juga disimpulkan bahwa efek agregat otonomi daerah, efektivitas otonomi daerah untuk mendorong pertumbuhan ekonomi terjadi. Hampir 13 tahun pelaksanaan otonomi daerah relatif efektif dalam membawa perubahan dalam pertumbuhan ekonomi regional, terutama untuk peningkatan pendapatan per kapita masyarakat. Namun, kemampuan pemerintah daerah dalam pengelolaan keuangan daerah masih perlu terus ditingkatkan dan diperkuat.

\section{DAFTAR PUSTAKA}

Amstrong, H dan Taylor, J., (2001). Regional Economics and
Policy. Malden, MA: Blackwell.

Akai, Nobuo dan Sakata, Masayo. (2002). Fiscal decentralization contributes to economic growth: evidence from statelevel cross-section data for the United States. Journal of Urban Economics, 52 (2002) 93-108.

Barro, Robert J. (1988). Government spending in a simple model of endogenous growth. NBER Working Paper Series 2588. National Bureau of Economic Research. Harvard University. (2003). Determinants of economic growth in a panel countries. Annals of Economics and Finance, 4, 231-274. Peking University Press.

Blanchard, Olivier. (2009). Macroeconomics. Fifth Edition. Pearson Prentice Hall.

Davoodi, Hamid dan Zou, Heng-Fu. (1998). Fiscal decentralization and economic growth: A crosscountry study. Journal of Urban Economics, 43, 244257.

Enders, Walter. (2010). Applied Econometric Time Series. 3ed. US: John Wiley \& Sons, Inc.

Enikolopov, Ruben dan Zhuravskaya. (2007). Decentralization and political institutions. Journal of Public Economics, 91 (2007) 2261-2290. Elsevier B.V.

Feltenstein, Andrew dan Iwata, $\mathrm{S}$ h i g e r u. ( ( $\left.\begin{array}{llll}2 & 0 & 0 & 5\end{array}\right)$ Decentralization and macroeconomic performance in China: Regional autonomy 
has its costs. Journal of Development Economics, 76 (2005) 481-501. Elsevier B.V.

Freinkman, Lev dan Plekhanov, Alexander. (2008). Fiscal decentralization in rentier regions: Evidence from Russia. World Development, Vol. 37, No. 2, pp. 503-512. Elsevier Ltd.

Hodrick, R. dan Prescott, E. (1981). Post-war U.S. Business Cycles: An Empirical Investigation. Working Paper, Carnegie-Mellon, University. Reprinted in Journal of Money, Credit, and Banking, (29/1), February 1997.

Iimi, Atsushi. (2005). Decentralization And Economic Growth Revisited: An empirical note. Journal of Urban Economics, 57 (2005) 449-461.

Jin, Jing dan Zou, Heng-Fu. (2005). Fiscal decentralization, revenue and expenditure assignments, and growth in China. Journal of Asian Economics, 16 (2005), 10471064. Elsevier Inc.

Litvak, Jenny., Ahmad, Junaid., dan Bird, Richard. (1998). Rethinking decentralization in developing countries. Sector Studies Series. USA: The World Bank.

Martinez-Vasquez, Jorge dan McNab, Robert M. (2003). Fiscal decentralization and economic growth. World Development, Vol. 31, No. 9, pp. 1597-1616. Elsevier Ltd.

\footnotetext{
(2006). Fiscal $\mathrm{d}$ e c e n t r a 1 i z a t i o n, macrostability, and growth.
}

Revista de Economia Publica, 179 (4/2006), 25-49. Instituto de Estudios Fiscales.

Mahi, Raksaka dan Adriansyah. (2002). History Of Central Financial Transfers To The Regions. Indonesia: LPEM FE University of Indonesia.

Martowardojo, Agus. (2012, October 11). A Decade of Regional Autonomy in the Eyes of The Minister of Finance. Retrieved from http://www.pajak.go.id,

Ministry of Finance. (2012). The financial notes of state budget draft 2013, fiscal year 2013. Additionally, fiscal year 19922010. Jakarta: Ministry of Finance.

Mochida, Nobuki. (2008). Fiscal decentralization and local public finance in Japan. Routledge Frontiers of Political Economy. New York: Routledge.

Oates, Wallace E. (1972). Fiscal Federalism. New York: Harcourt Brace Jovanovic. Also published in format of Paperback Edition 2011. UK: Edward Elgar Publishing Limited. , (1993). The role of fiscal decentralization in economic growth. Center for Institutional Reform and the Informal Sector.

Philip, Abachi Termehen dan Isah, Salamatu. (2012). An analysis of the effect of fiscal decentralization on economic growth in Nigeria. International Journal of Humanities and Social Science, 2/ 8 (Special Issue- 
April 2012). USA: Centre for Promoting Ideas.

Prud'homme, R. (1995). On the dangers of decentralization. Policy Research, Working Paper 1252. Washington D.C: World Bank.

Ravn, Morten O., dan Uhlig, Harald. (2002). On adjusting the Hodrick-Prescott filter for the frequency of observations. The Review of Economics and Statistics, May 2002, 84 (2): 371-380. Harvard College and the Massachusetts Institute of Technology.

Rodriguez-Pose, Andres dan Kroijer, Anne. (2009). Fiscal decentralization and economic growth in Central and Eastern Europe. Journal of Growth and Change, 40/ 3 (September 2009), 387-417. Wiley Periodicals, Inc.

Rondinelli, D. (1989). Decentralizing Public Services in Developing Countries: Issues and Opportunities. Journal of Social, Political, and Economic Studies, 14 (1):7789. UNZ.

Saputra, Bambang. (2013). Pengaruh Desentralisasi Fiskal Terhadap Pertumbuhan Ekonomi dan Kesejahteraan Masyarakat. Jurnal Borneo Administrator, Volume 9/ No.1/2013.

Swasono, Fauziah. (2007). Fiscal decentralization and economic growth: Evidence from
Indonesia. Economics and Finance in Indonesia, 55, (2).

Thornton, John. (2007). Fiscal decentralization and economic growth reconsidered. Journal of Urban Economics, 61 (2007) 64-70. Elsevier Inc.

Tiebout, Charles M. (1956). A pure theory of local expenditures. The Journal of Political Economy, 64/ 5 (October 1956), 416-424. The University of Chicago Press.

Tirtosuharto, Darius. (2009). Regional Competitiveness in Indonesia: The Incentives of Fiscal Decentralization on State Efficiency and Economic Growth. Dissertation. George Mason University. Fairfax, VA.

Wibowo, Puji. (2008). Analysis the i m p a t of fi s c a 1 decentralization on economic growth in the region. Journal of Public Finance, 5/ 1 (October 2008).

Xie, Danyang., Zou, Heng-fu., dan Davoodi, Hamid. (1999). Fiscal decentralization and economic growth in the United-States. Journal of Urban Economics, 45, 228239 (1999). Academic Press.

Zhang, Tao dan Zhou, Heng-fu. (1998). Fiscal decentralization, public spending, and economic growth in China. Journal of Public Economics, 67, 221240. Elsevier Science S.A. 